\title{
Down regulation of lactate dehydrogenase initiates apoptosis in HeLa and MCF-7 cancer cells through increased voltage- dependent anion channel protein and inhibition of BCL2
}

\author{
Suhail Al-Salam ${ }^{1}$, Karthishwaran Kandhan ${ }^{1}$ and Manjusha Sudhadevi ${ }^{1}$ \\ ${ }^{1}$ Department of Pathology, College of Medicine \& Health Sciences, United Arab Emirates University, AIAin, UAE \\ Correspondence to: Suhail Al-Salam, email: suhaila@uaeu.ac.ae \\ Keywords: cancer metabolism; LDHA; apoptosis; VDAC \\ Received: February 23, $2021 \quad$ Accepted: March 25, $2021 \quad$ Published: April 27, 2021 \\ Copyright: ( $) 2021$ Al-Salam et al. This is an open access article distributed under the terms of the Creative Commons Attribution License (CC BY \\ 3.0), which permits unrestricted use, distribution, and reproduction in any medium, provided the original author and source are credited.
}

\section{ABSTRACT}

Malignant cells commonly use aerobic glycolysis for ATP production; this is known as the Warburg effect, where pyruvate is converted to lactate, by enzyme lactate dehydrogenase A (LDH-A). In this study, we have investigated the effect of inhibition of LDH-A on cells viability and identifying the mechanism of cell death in HeLa and MCF-7 cancer cells.

Human cervical cancer HeLa cell line and breast cancer MCF-7 cell line were used to investigate the effect of inhibition of LDH-A by sodium oxamate on cell survival and proliferation using western blot, spectrophotometry, and immunofluorescent study.

There was significant reduction in LDH-A $(P<0.001)$ and cell viability $(P<0.001)$ in a dose-dependent mode in both HeLa and MCF-7 SO-treated cancer cells. The voltage-dependent anion channel (VDAC) protein was significantly increased $(P<0.001)$ in association with decreased LDH-A. The proapoptotic proteins; cytochrome C $(P<0.001)$, BAX $(P<0.001)$, cleaved caspase-3 $(P<0.001)$, cleaved caspase-8 $(P<0.001)$, and cleaved caspase-9 $(P<0.001)$ were significantly increased in association with decreased LDH-A. While, the anti-apoptotic protein Bcl2 was significantly decreased $(P<0.001)$ in association with decreased LDH-A.

We conclude that Inhibition of LDH-A can decrease cells viability through activation of intrinsic apoptotic pathway via increased VDAC protein and inhibition of $\mathrm{BCl} 2$ as well as activation of the extrinsic apoptotic pathway through activation of caspase-8.

\section{INTRODUCTION}

Malignant cells commonly use aerobic glycolysis for ATP production; this is known as the Warburg effect [1]. Pyruvate is converted to lactate by enzyme lactate dehydrogenase $\mathrm{A}$ (LDH-A) where nicotinamide adenine dinucleotide $(\mathrm{NAD}+)$ is generated from NADH in this process [2]. The production of $\mathrm{NAD}^{+}$is required by glyceraldehyde 3-phosphate dehydrogenase to maintain glycolysis and ATP production [2]. LDH, which owns two subunits LDH-A and LDH-B, is an enzyme commonly existing in human cells [3]. LDH-A catalyzes the conversion of pyruvate to lactate with the liberation of $\mathrm{NAD}^{+}$, which possesses a vital role in glycolysis. It has long been noted that LDH- A expression is upregulated in human neoplastic tissues [3].
Recently, many studies have shown that LDH-A plays a vital role in maintaining tumor growth and progression [4]. Furthermore, relevant studies have demonstrated that inhibition of LDH-A induces oxidative stress and suppresses tumor growth in a variety of cancer cell lines $[5,6]$.

Since aerobic glycolysis is the favored way of ATP production in cancer cells, it becomes a very attractive target for cancer therapies [7].

Sodium oxamate (SO) is a competitive inhibitor of LDH-A, hence, we use SO to block aerobic glycolysis and reduces the main energy source in cancer cells [8]. However, the detailed mechanism remains largely unclear. In this study we will investigate changes in apoptotic and oxidative stress pathways in association with the use of sodium oxamate in cervical (HeLa) and breast (MCF- 
7) cancer cell lines aiming in identifying mechanism of cancer cell death following SO treatment.

\section{RESULTS}

\section{Effect of sodium oxamate on cell proliferation}

The effect of SO on cell proliferation was determined by MTT assay (Figure 1). The proliferation of HeLa and MCF-7 cells was significantly inhibited by various concentration of SO $(20-100 \mathrm{mmol} / \mathrm{L})$. The inhibitory effect was observed after 24-hour of incubation. Figure 1 reveals treatment with $\mathrm{SO}$ can lead to significant inhibition of proliferation. The SO inhibitory effect was dose-related. The treatment of $60 \mathrm{mmol} / \mathrm{L}$ of SO revealed almost $40 \%$ cell inhibition on both HeLa and MCF-7 cells (Table 1). Hence, we have selected the 40 and $60 \mathrm{mmol} / \mathrm{L}$ concentrations of SO for further analysis. Treatment with SO has shown dose-related inhibition of cell growth of both HeLa cells and MCF-7 cells (Figures 1 and 2).

\section{Changes in the activities of antioxidant enzymes}

\section{SO reduces superoxide dismutase (SOD) activity}

SO (40 and $60 \mathrm{mmol} / \mathrm{L}$ ) treatment significantly reduced the activity of SOD in HeLa and MCF-7 cells, when compared with untreated control cells (Figure 3). The two tested doses, 40 and $60 \mathrm{mmol} / \mathrm{L}$ of $\mathrm{SO}$, significantly decreased SOD levels in both HeLa and MCF7 cancer cells, suggesting that SO increased reactive oxygen species (ROS) content in both HeLa and MCF7 cancer cells.

\section{SO decreases reduced glutathione (GSH)}

Reduced GSH is an important cellular antioxidant through donating thiol groups. There was a significant reduction of reduced GSH levels in SO treated HeLa and MCF7 cancer cells (Figure 4). The two tested doses, 40 and $60 \mathrm{mmol} / \mathrm{L}$ of SO, significantly decreased GSH levels in both HeLa and MCF7 cancer cells, suggesting that SO increased ROS content in both HeLa and MCF7 cancer cells.

\section{Changes in the LDH-A level}

In this study, LDH-A was significantly decreased in SO- treated groups when compared to control cancer cells in both HeLa and MCF-7 (Figure 5). We have noticed $\mathrm{LDH}-\mathrm{A}$ reduction is even greater in $60 \mathrm{mmol} / \mathrm{L}$ compared to $40 \mathrm{mmol} / \mathrm{L}$ treated groups, suggesting a dose-response activity of SO on LDH-A. Accordingly, SO treatment significantly inhibited LDH-A activity in cancer cells, while ROS content was distinctly increased.

\section{Correlation between the expression of LDH-A and VDAC}

The effect of SO on the expression pattern of VDAC, LDH-A and pyruvate dehydrogenase (PDH) in HeLa and MCF-7 cells was analyzed by western blot. The expressions of VDAC was found to be significantly increased in 40 and $60 \mathrm{mmol}$ SO- treated HeLa and MCF7 cells when compared to control cells. Whereas, similar concentrations of SO had shown significant decrease in the expression of LDH-A and PDH when compared to control non-treated HeLa and MCF-7 cancer cells (Figure 6).

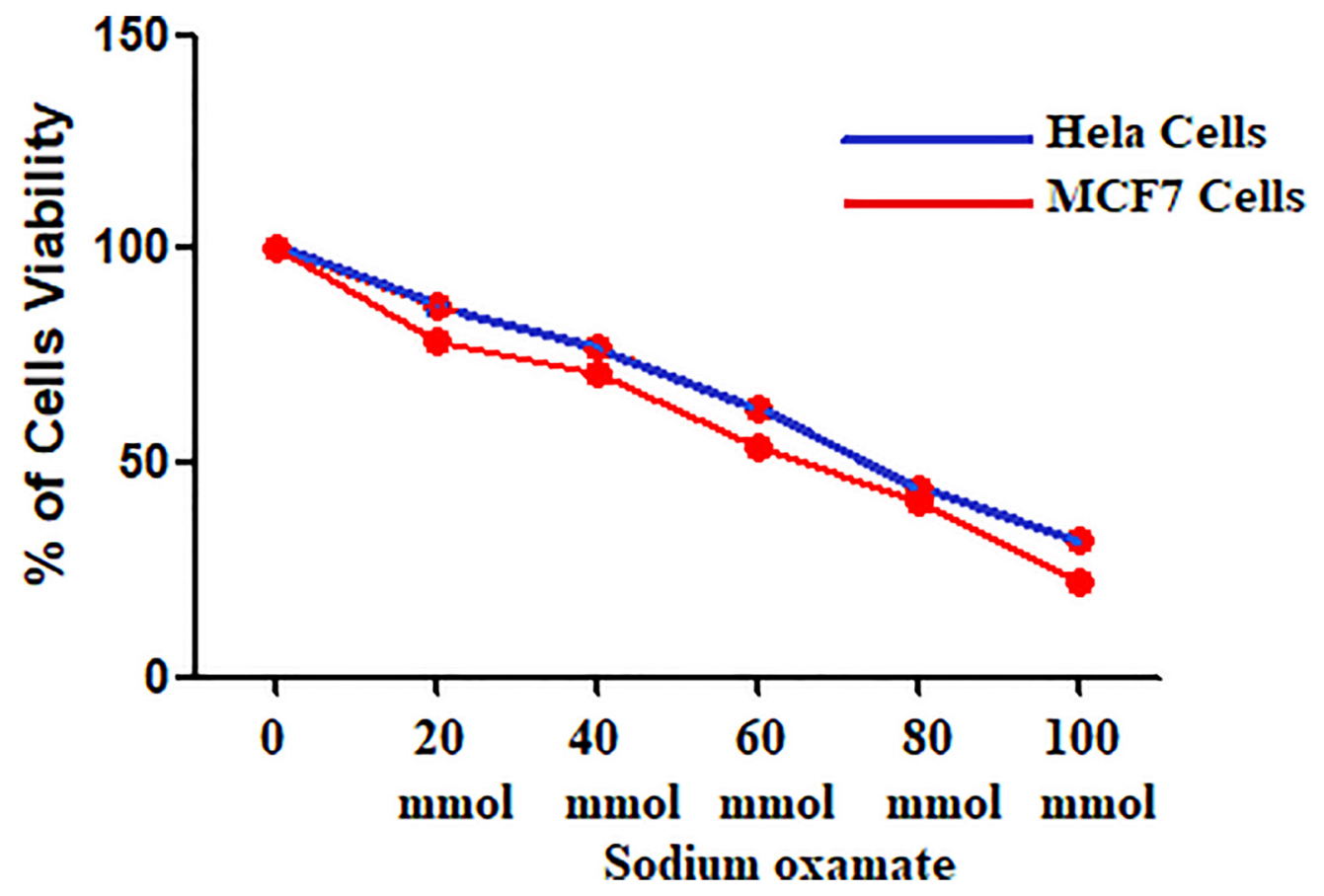

Figure 1: HeLa and MCF-7 Cell viability at different concentrations of sodium oxamate. 
Table 1: HeLa and MCF-7 cells viability at different concentrations of sodium oxamate

\begin{tabular}{ccccc}
\hline Concentration (mmol/L) & $\begin{array}{c}\text { HeLa Cell } \\
\text { Viability }\end{array}$ & $\boldsymbol{P}$ Value & $\begin{array}{c}\text { MCF-7 Cell } \\
\text { Viability }\end{array}$ & $\boldsymbol{P}$ Value \\
\hline 0 & 100 & & 100 & \\
20 & $78.3 \pm 1.35$ & $<0.001$ & $86.4 \pm 1.8$ & $<0.001$ \\
40 & $71.3 \pm 0.9$ & $<0.001$ & $76.7 \pm 0.9$ & $<0.001$ \\
60 & $53.9 \pm 0.81$ & $<0.0001$ & $62.9 \pm 0.9$ & $<0.0001$ \\
80 & $40.8 \pm 0.72$ & $<0.0001$ & $44.29 \pm 0.6$ & $<0.0001$ \\
100 & $22.6 \pm 0.4$ & $<0.0001$ & $32.06 \pm 0.36$ & $<0.0001$ \\
\hline
\end{tabular}

\section{Expression of apoptotic and anti-apoptotic proteins in relation to decreased LDH-A}

The effect of SO on the expression pattern of cleaved caspase 3, cleaved caspase 8 , cleaved caspase 9 , Bax, cytochrome c, and Bcl-2 in HeLa and MCF-7 cells was analyzed by western blot. The expressions of cleaved caspase 3 , cleaved caspase 8 , cleaved caspase 3 , Bax, and cytochrome $\mathrm{C}$, proteins were found to be significantly increased in $40 \mathrm{mmol}$ and $60 \mathrm{mmol} \mathrm{SO}$ treated HeLa and MCF-2 cells when compared to control non-treated HeLa and MCF-7 cells. Whereas, similar concentrations of SO had shown significant decrease in the expression of $\mathrm{Bcl}-2$ in treated $\mathrm{HeLa}$ and MCF-7 cells when compared to control non-treated HeLa and MCF-7 cells (Figures 7-10).

\section{Expression of proliferative markers in relation to SO treatment}

SO treatment has shown decrease in the expression of p-NFK-B, VEGF, BMI-1 and ki-67 at $60 \mathrm{mmol}$ concentration, suggesting that $\mathrm{SO}$ can reduce cellular proliferation (Figures 11, 12).

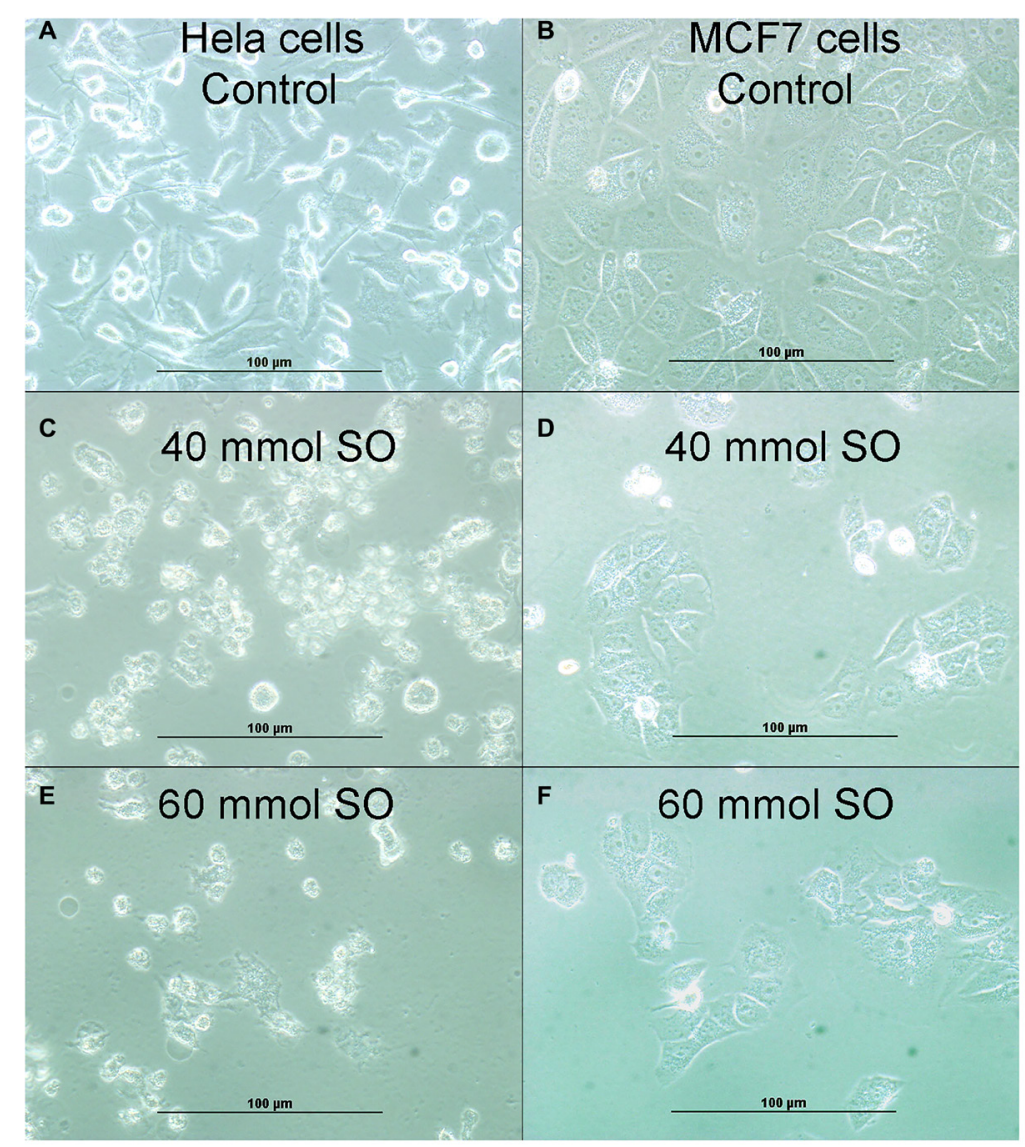

Figure 2: (A) Showing cellular growth of untreated HeLa cells. (B) Showing cellular growth of untreated MCF-7 cells. (C) Showing reduction of cellular proliferation in 40 mmol-treated HeLa cells. (D) Showing reduction of cellular proliferation in $40 \mathrm{mmol}$-treated MCF-7 cells. (E) Showing more reduction of cellular proliferation in 60 mmol-treated HeLa cells. (F). Showing more reduction of cellular proliferation in $60 \mathrm{mmol}$-treated MCF-7 cells. 


\section{DISCUSSION}

Cancer cells produce a large amount of energy through glycolysis even in the presence of sufficient oxygen [1-3]. LDH-A, a key regulator of glycolysis, reversibly catalyzes the conversion of pyruvate to lactate. In this study, we show SO significantly reduces LDH-A in a dose-dependent mode.

We also show SO significantly inhibits the viability of human cervical (HeLa) and breast (MCF-7) cancer cells in a dose-dependent fashion.

Increased levels of LDH-A have been reported in several types of cancers [9-11], and their levels of expression have been correlated with clinical stages in esophageal, pancreatic, prostate carcinomas; suggesting that overexpression of LDH-A has proliferative role on cancer cells. These studies [9-11] further support the concept that therapies targeting LDH-A may provide useful strategies in controlling cancer progression. Our immunofluorescent staining results have also shown a decrease in the expression of growth signals markers; p-NFK-B, BMI-1, VEGF and ki-67 in SO treated HeLa cells and MCF-7 cells suggesting an association with the decreased LDH-A in these cells.

In addition, we have shown treatment with SO significantly augments ROS production leading to a significant reduction in SOD and GSH levels in SO-treated cancer cells suggesting that inhibition of LDH-A plays an important role in the induction of ROS. Zhao $\mathrm{Z}$ et al. have also shown that $\mathrm{SO}$ treatment significantly augments ROS production [12]. Reports have shown increased ROS can induce apoptosis [13-15].

We have also shown SO significantly increases proapoptotic proteins BAX and cytochrome $\mathrm{c}$. In addition,
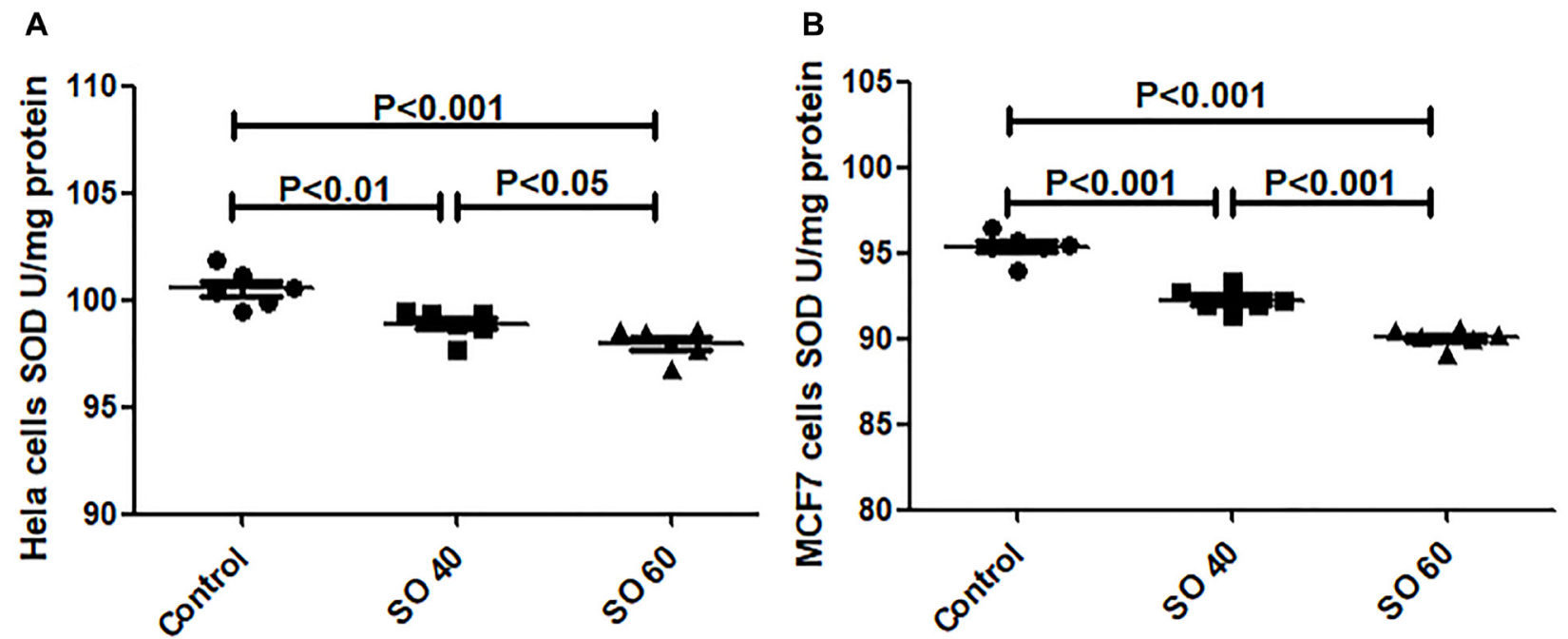

Figure 3: Anti-oxidant activity of SOD in SO-treated HeLa (A) and MCF-7 (B) cell lines.
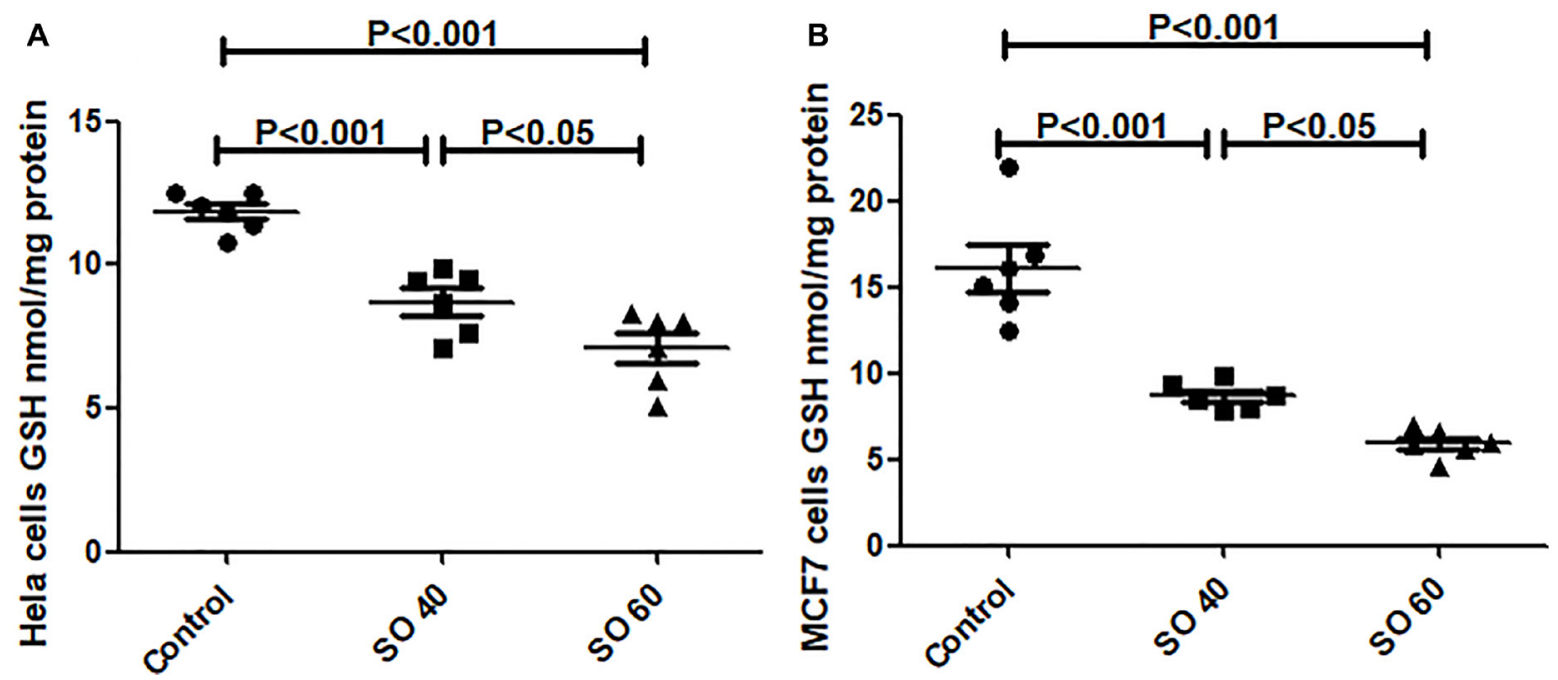

Figure 4: GSH levels in SO- treated HeLa (A) and MCF-7 (B) cancer cell lines. 
there is significant increase in the initiating active caspases; cleaved caspase 8 and 9 and terminal executer cleaved caspase 3 which is accompanied by significant reduction in antiapoptotic protein $\mathrm{Bcl} 2$. These findings support apoptotic role of SO. Chandan et al. have shown inhibition of LDH-A can lead to apoptosis, which supports our finding [16].

Interestingly, we also show SO-treated cancer cells have significant increase in VDAC protein. VDAC protein has also been shown to play an important role in apoptosis
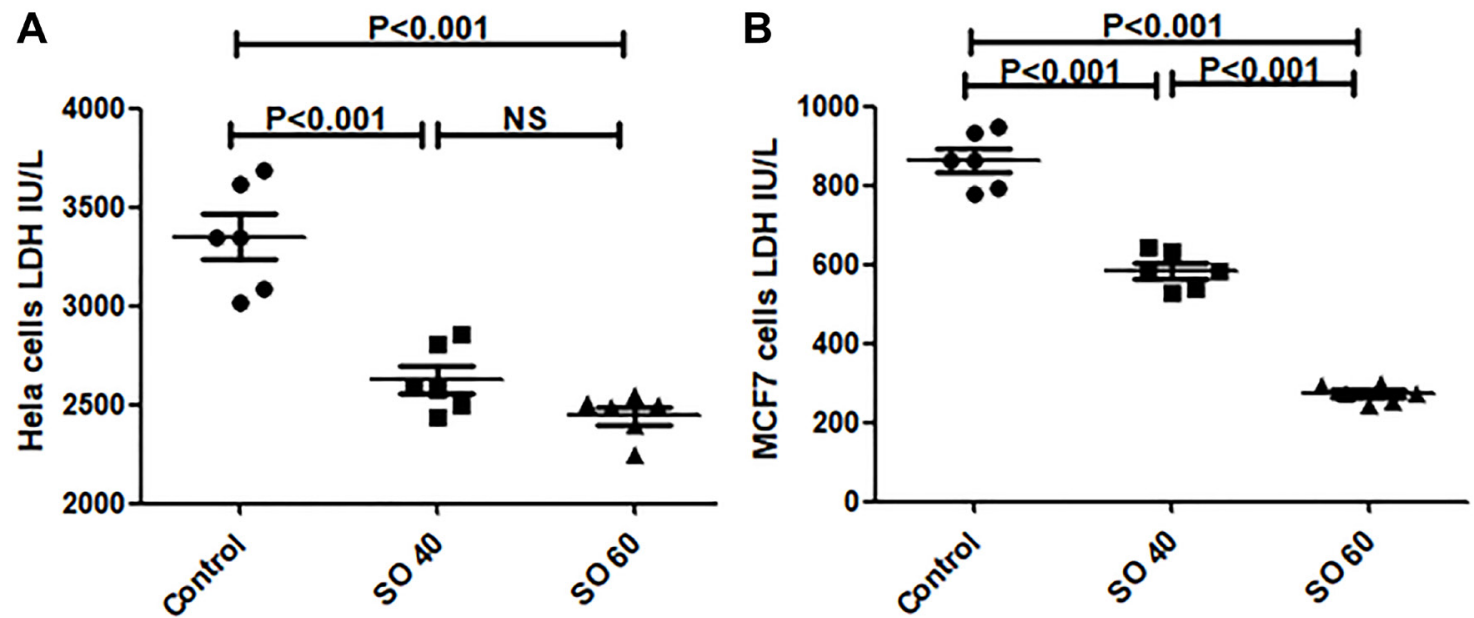

Figure 5: Sodium Oxamate inhibits LDH enzyme activity in HeLa (A) and MCF-7 (B) cancer cells. Cells were treated with 0, 40, 60 mM sodium oxamate for 24 hour.

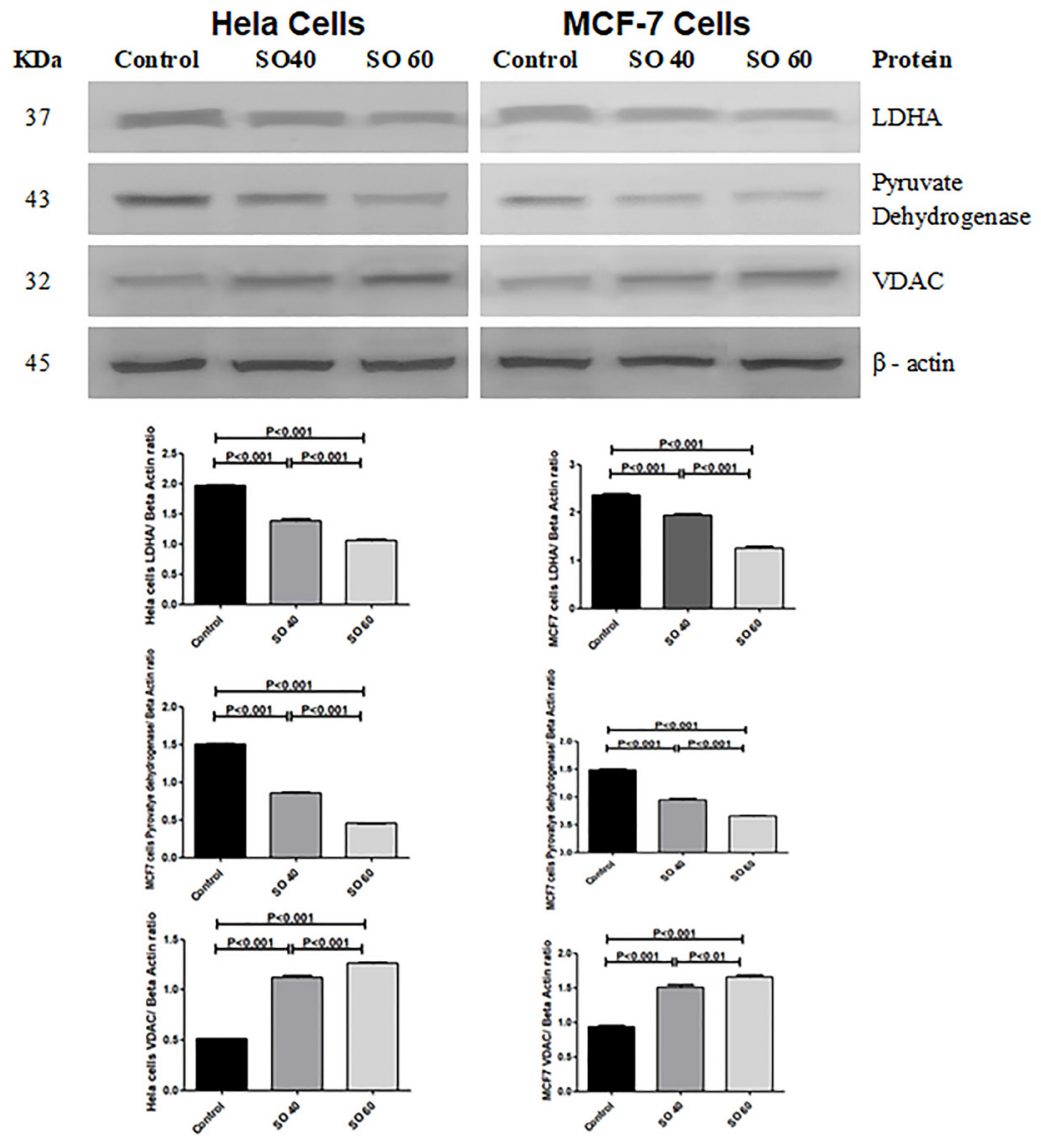

Figure 6: Expression of LDHA, PDH and VDAC proteins in $40 \mathrm{mmol}$ and $60 \mathrm{mmol}$ SO treated HeLa and MCF-7 cancer cells compared to control non-treated HeLa and MCF-7 cancer cells. 
[17]. Following the initiation of apoptotic signals there is increased permeability of VDAC, which allows the release of proapoptotic proteins such as cytochrome $\mathrm{c}$ from the mitochondria. Although cytochrome c plays a crucial role in oxidative phosphorylation within the mitochondria, in the cytosol it activates caspases, which play a major role in programed cell death [18]. While the mechanism of VDAC-enabled cytochrome c release has not yet been fully understood, there have been reports suggest that oligomerization between individual subunits can create

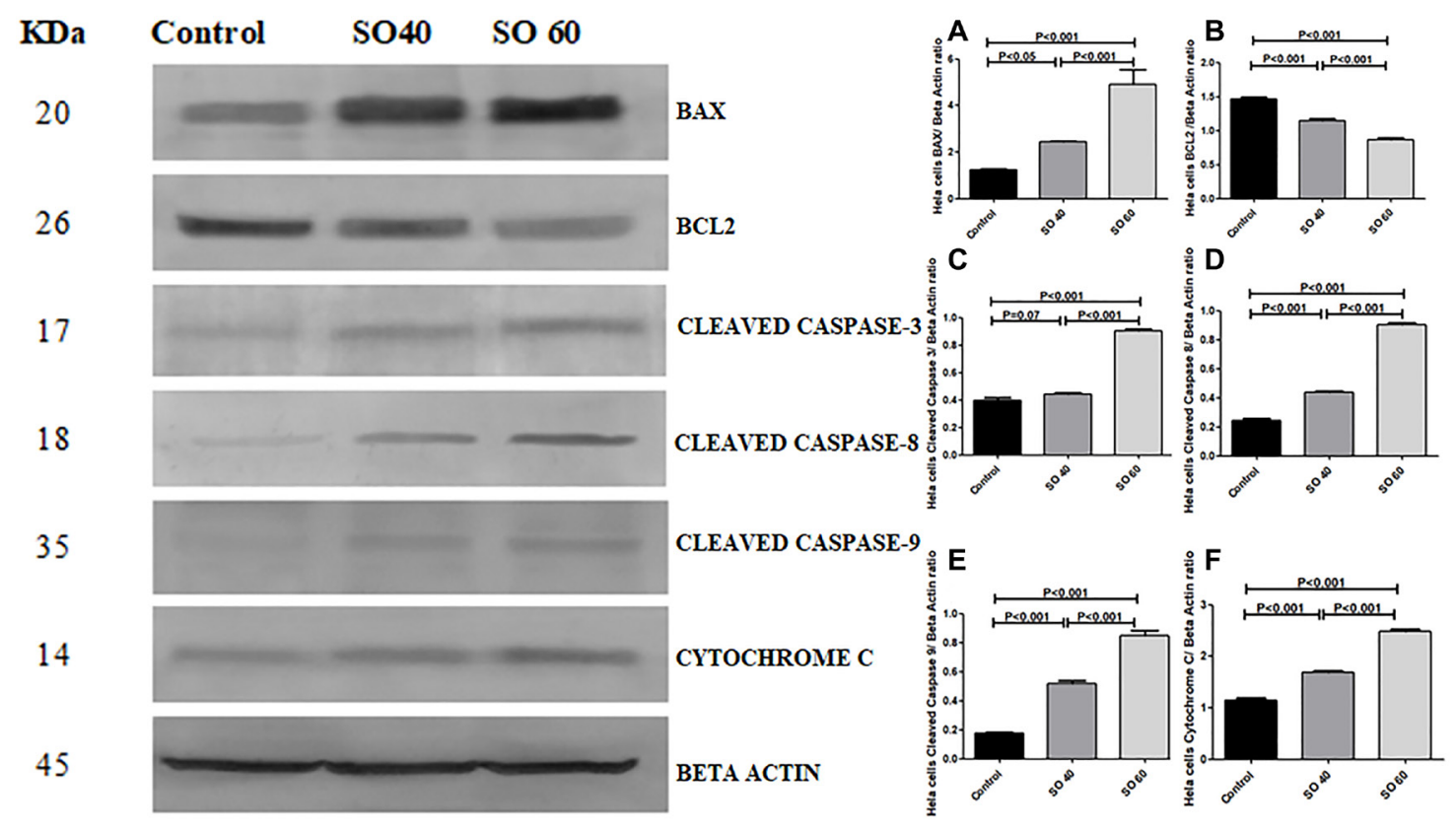

Figure 7: Expression of apoptotic proteins Bax, cleaved caspase-3, cleaved caspase-8, cleaved caspase-9, cytochrome $c$ and anti-apoptotic proteins Bcl2 in $40 \mathrm{mmol}$ and $60 \mathrm{mmol}$ SO treated HeLa cancer cells compared to control nontreated HeLa cells.
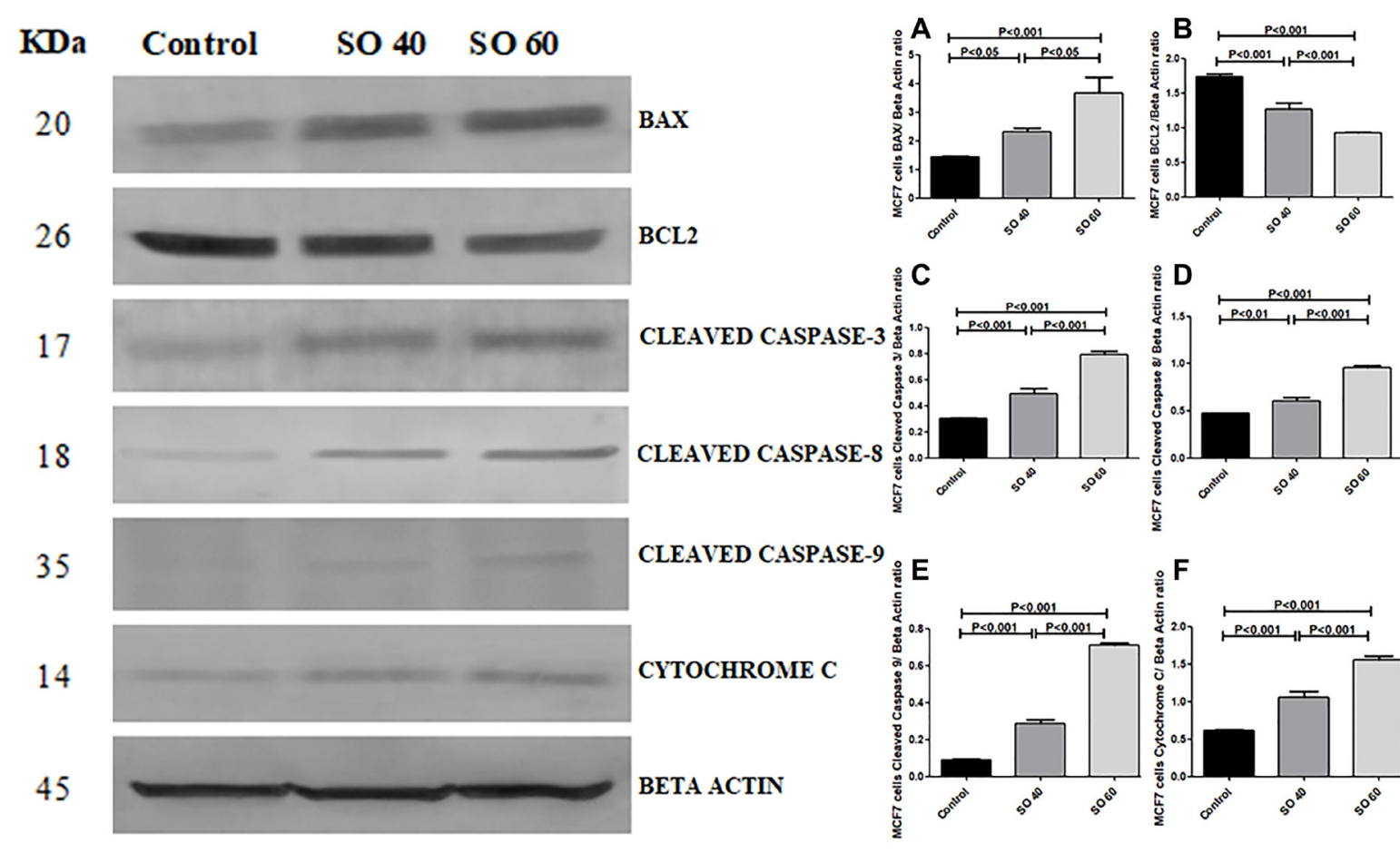
a large stretchy pores through which cytochrome c can pass [19]. Remarkably, the release of cytochrome $\mathrm{c}$ is also regulated by Bax, which interacts directly with VDAC to increase pore size and promote cytochrome c release, whereas anti-apoptotic $\mathrm{Bcl} 2$ produces the opposite effect [20]. In fact, it has been shown that antibodies which are capable of inhibiting VDAC also interfere with Baxmediated cytochrome c release [21].

Zalk et al. have suggested that VDAC overexpression can lead to increased cell death since higher VDAC expression favors VDAC oligomerization [19]. Moreover, it has been advocated that oligomeric
VDAC mediates the release of cytochrome c [19], because the internal diameter of a single VDAC pore is 2.5-3.0 $\mathrm{nm}$, which is insufficient to pass a folded protein [22]. The increased VDAC has been shown to assemble to form polymers that increases the diameter of VDAC and allows the release of cytochrome c [22]. Reports have shown upregulation of $\mathrm{Bcl} 2$ prevents VDAC oligomerization and then apoptosis [23, 24].

Our study has shown for the first time a significant dose-related increase in VDAC protein in SO-treated HeLa and MCF7 cells as compared with control cancer cells; suggesting SO has a crucial effect on VDAC production

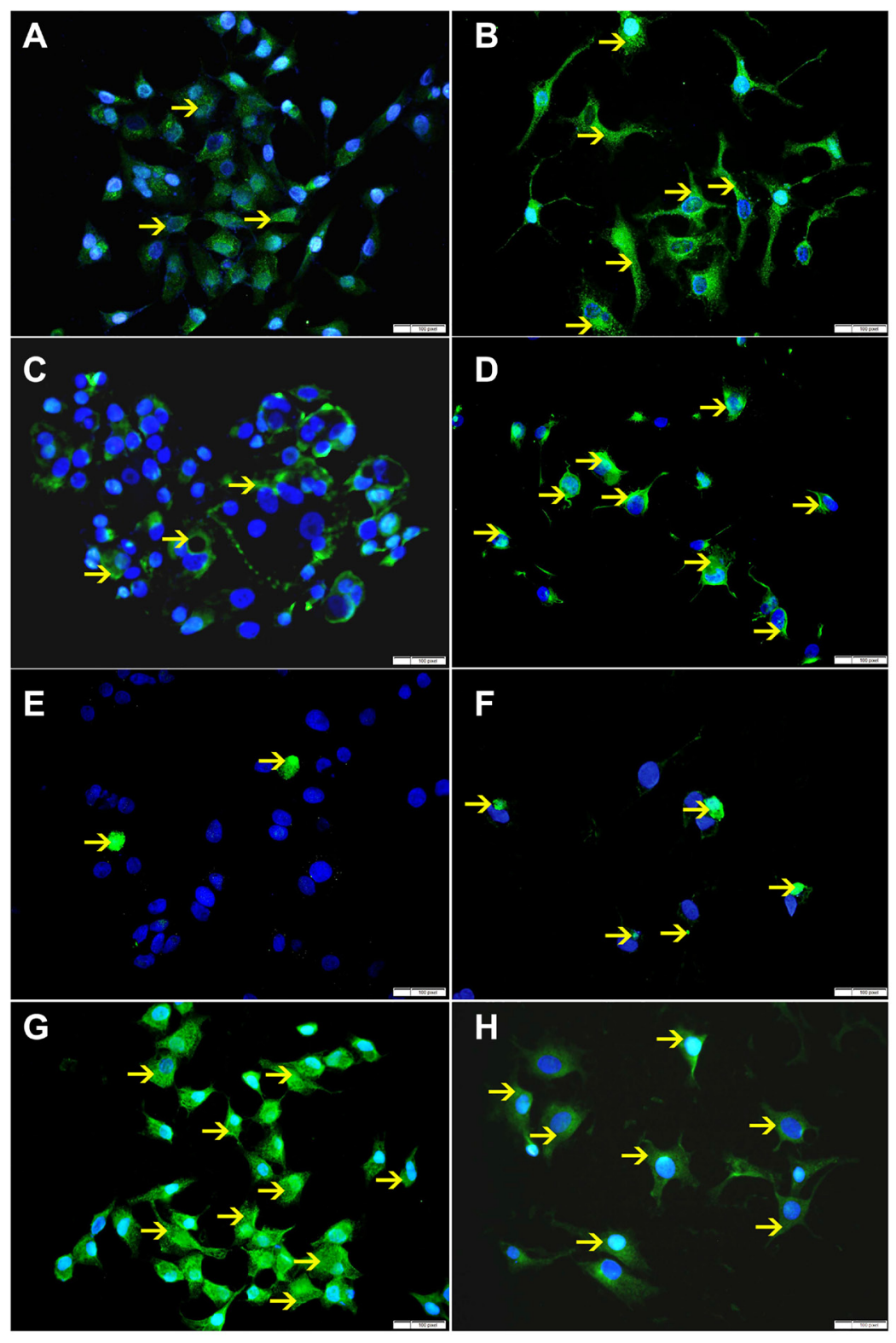

Figure 9: (A) Showing low cytoplasmic expression of Bax by non-treated HeLa cells (arrow). (B) Showing higher cytoplasmic expression of Bax by SO 60mmol treated HeLa cells (arrow). (C) Showing low cytoplasmic expression of VDAC by non-treated HeLa cells (arrow). (D) Showing higher cytoplasmic expression of VDAC by SO $60 \mathrm{mmol}$ treated HeLa cells (arrow). (E) Showing few apoptotic bodies expressing cleaved caspase-3 in non-treated HeLa cells (arrow). (F) Showing higher number of apoptotic bodies expressing cleaved caspase-3 in SO 60mmol treated HeLa cells (arrow). (G) Showing high cytoplasmic expression of Bcl-xL by non-treated HeLa cells (arrow). (H) Showing lower cytoplasmic expression of Bcl-xL by SO 60 mmol treated HeLa cells (arrow). 
either directly or through the increase in free radicals or a decrease in LDH-A.

The increase in VDAC can lead to increase in cell death through activation of the intrinsic pathway of apoptosis by enhancing the release of cytochrome $\mathrm{c}$ and inactivation of $\mathrm{Bcl} 2$, which may be the main mechanism of apoptosis in our study [19].

We have also shown a significant increase in cleaved caspase- 8 suggesting activation of extrinsic pathway of apoptosis in SO-treated HeLa and MCF7 cancer cells.
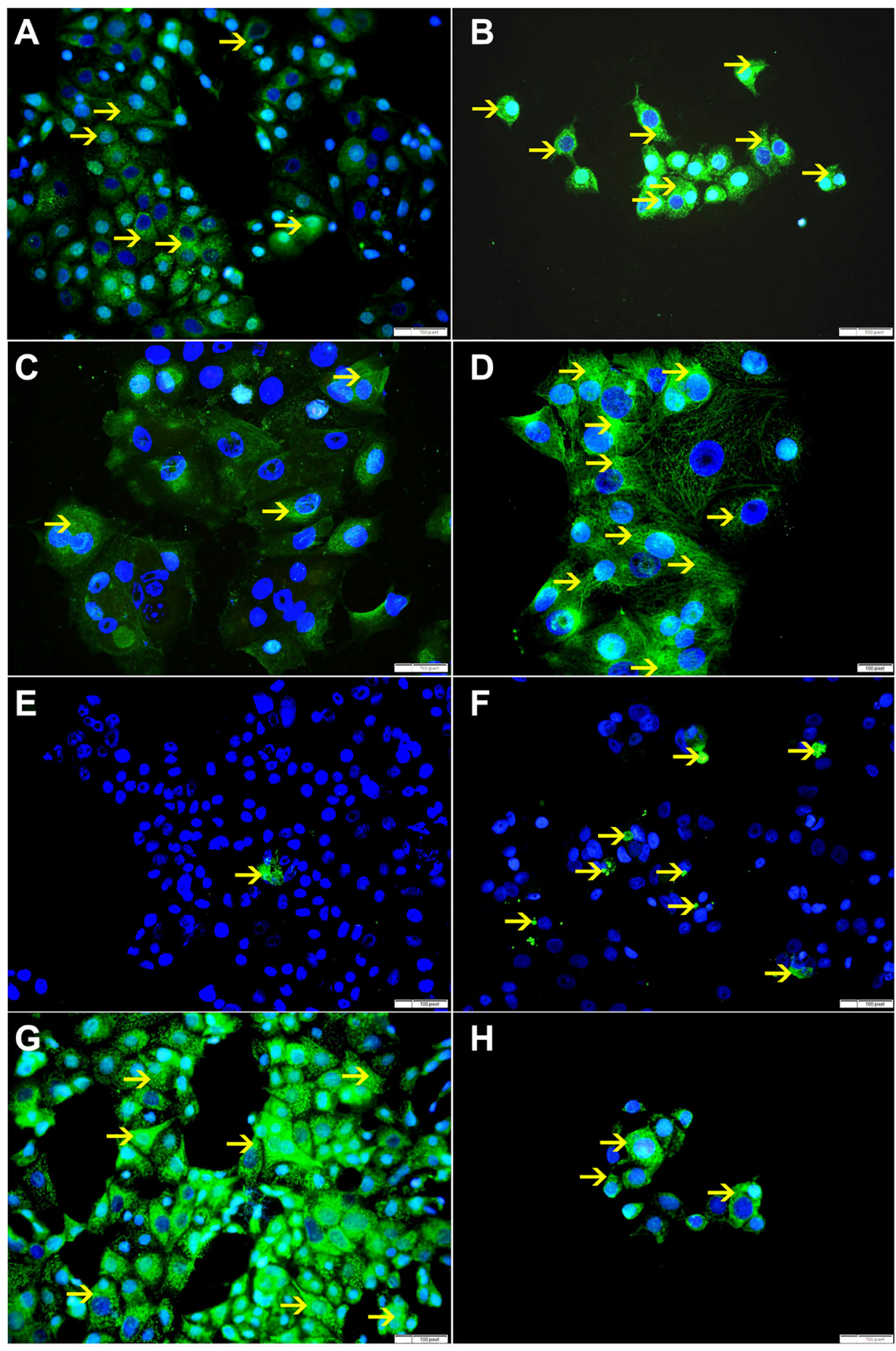

Figure 10: (A) Showing cytoplasmic expression of Bax by non-treated MCF-7 cells (arrow). (B) Showing higher cytoplasmic expression of Bax by SO $60 \mathrm{mmol}$ treated MCF-7 cells (arrow). (C) Showing low cytoplasmic expression of VDAC by non-treated MCF-7 cells (arrow). (D) Showing higher cytoplasmic expression of VDAC by SO $60 \mathrm{mmol}$ treated MCF-7 cells (arrow). (E) Showing few apoptotic bodies expressing cleaved caspase-3 in non-treated MCF-7 cells (arrow). (F) Showing higher number of apoptotic bodies expressing cleaved caspase-3 in SO 60mmol treated MCF-7 cells (arrow). (G) Showing high cytoplasmic expression of Bcl-xL by non-treated MCF-7 cells (arrow). (H) Showing lower cytoplasmic expression of Bcl-xL by SO 60 mmol treated MCF-7 cells (arrow). 
There was no previous reports on activation of extrinsic pathway of apoptosis in association with SO-treated cancer cells. It is possible that the activation of caspase- 8 is related to increase in free radical production associated with SO treatment. This is supported by other studies, which also show activation of caspase- 8 by oxidative stress $[25,26]$.

In conclusion, the Inhibition of LDH-A can decrease cells viability through activation of intrinsic apoptotic pathway via increased VDAC protein and inhibition of $\mathrm{Bcl} 2$ as well as activation of the extrinsic apoptotic pathway through activation of caspase- 8 .

\section{MATERIALS AND METHODS}

\section{Chemicals}

Sodium oxamate was supplied by Sigma-Aldrich (St. Louis, MO, USA). All other chemicals were procured from Merck (analytical grade).

\section{Cell culture}

The human cervical cancer cell line (HeLa) and breast cancer cell line (MCF-7) were obtained

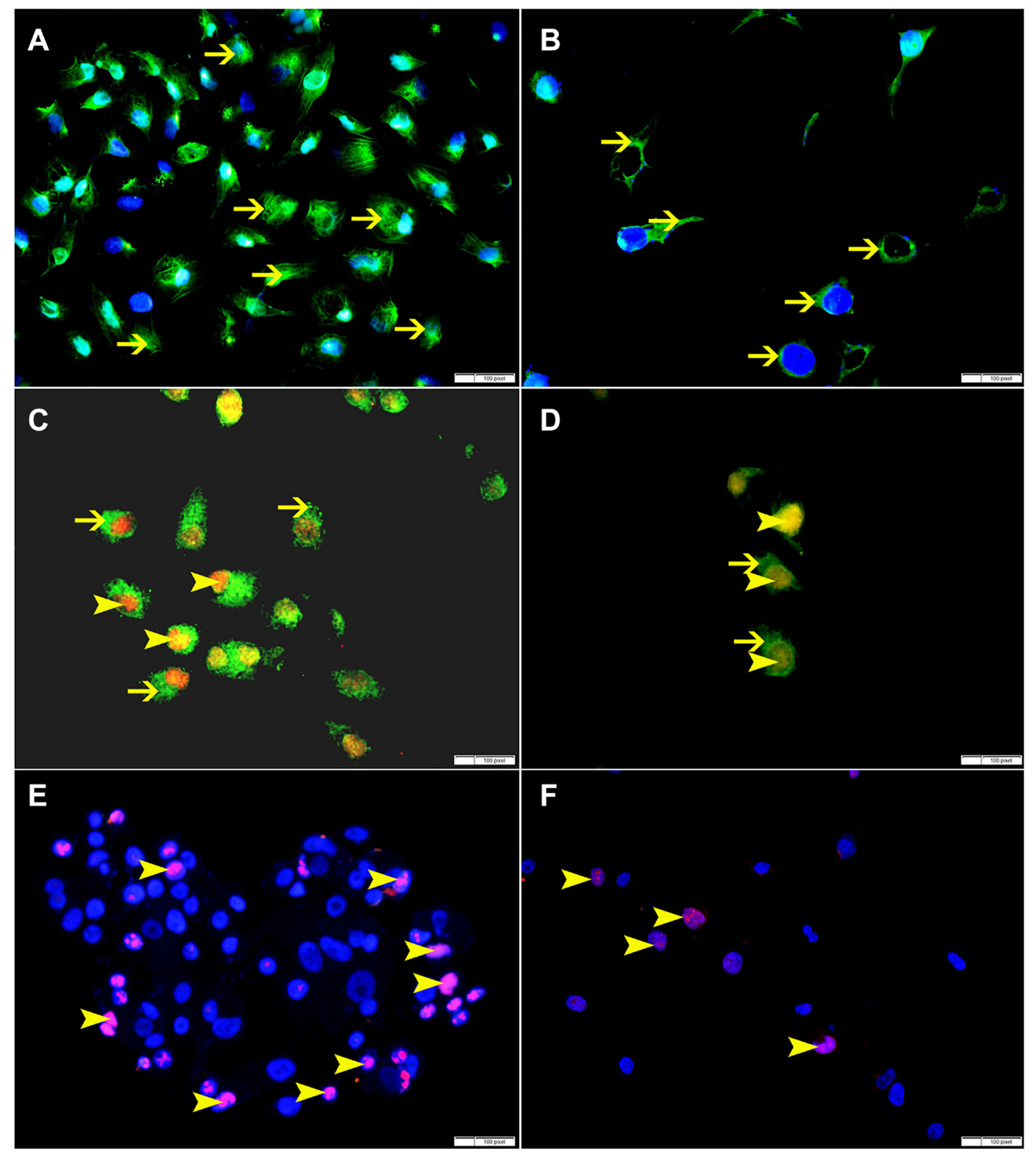

Figure 11: (A) Showing higher cytoplasmic expression of p-NFKB by non-treated HeLa cells (arrow). (B) Showing lower cytoplasmic expression of p-NFKB by SO $60 \mathrm{mmol}$ treated HeLa cells (arrow). (C) Showing higher cytoplasmic expression of VEGF (thin arrow) and nuclear expression of BMI-1 (arrowhead) by non-treated HeLa cells. (D) Showing lower cytoplasmic expression of VEGF (thin arrow) and nuclear expression of BMI-1 (arrowhead) by SO 60 mmol treated HeLa cells. (E) Showing higher number of cells expressing ki-67 in non-treated HeLa cells (arrow). (F) Showing lower number of cells expressing ki-67 in SO 60 mmol treated HeLa cells (arrow). 
from ATCC, Rockville, MD, USA. Entire cell culture experiments were conducted using pre-sterile consumables and followed aseptic techniques already in place. The HeLa cell was grown as a monolayer in Dulbecco's Modified Eagle's Medium (DMEM) and the MCF-7 cell was grown as a monolayer in MEM with $10 \%$ FBS, $200 \mathrm{mM}$ L-glutamine, 10,000 U/mL penicillin, and $10 \mathrm{mg} / \mathrm{mL}$ streptomycin at $37^{\circ} \mathrm{C}$ in $5 \% \mathrm{CO}_{2}$. Cells were harvested by trypsinization once $80 \%$ confluency was achieved during subculture. Stocks were maintained in $25 \mathrm{~cm}^{2}$ tissue culture flasks.

\section{MTT (3-(4,5-dimethylthiazol-2-yl)-2,5- diphenyltetrazolium bromide) assay}

The MTT assay, which detects mitochondrial dehydrogenase activity in living cells, was used to assess cytotoxicity [27]. Briefly, cells $\left(5 \times 10^{3}\right.$ cells/well $)$ plated in 96-well flat-bottom plates were exposed with an increasing range of concentration of $\mathrm{SO}$. After incubation, $10 \mu \mathrm{l}$ of MTT $(5 \mathrm{mg} / \mathrm{ml})$ in PBS were added to each well and allowed to develop color. DMSO was added to stop the reaction and the absorbance at $570 \mathrm{~nm}$ was read using Tecan infinite microplate reader.

\section{Cell treatments}

Both HeLa and MCF-7 cells were treated with $\mathrm{SO}$ in different concentrations and incubated at $37^{\circ} \mathrm{C}$ in $5 \% \mathrm{CO}_{2}$ incubator. After $24 \mathrm{~h}$ incubation, the cells were harvested by trypsinization for further experiments.

Group I: Control (Untreated HeLa/MCF-7 cells) Group II: HeLa/MCF-7 cells + SO (40 mmol/L)

Group III: HeLa/MCF-7 cells $+\mathrm{SO}(60 \mathrm{mmol} / \mathrm{L})$

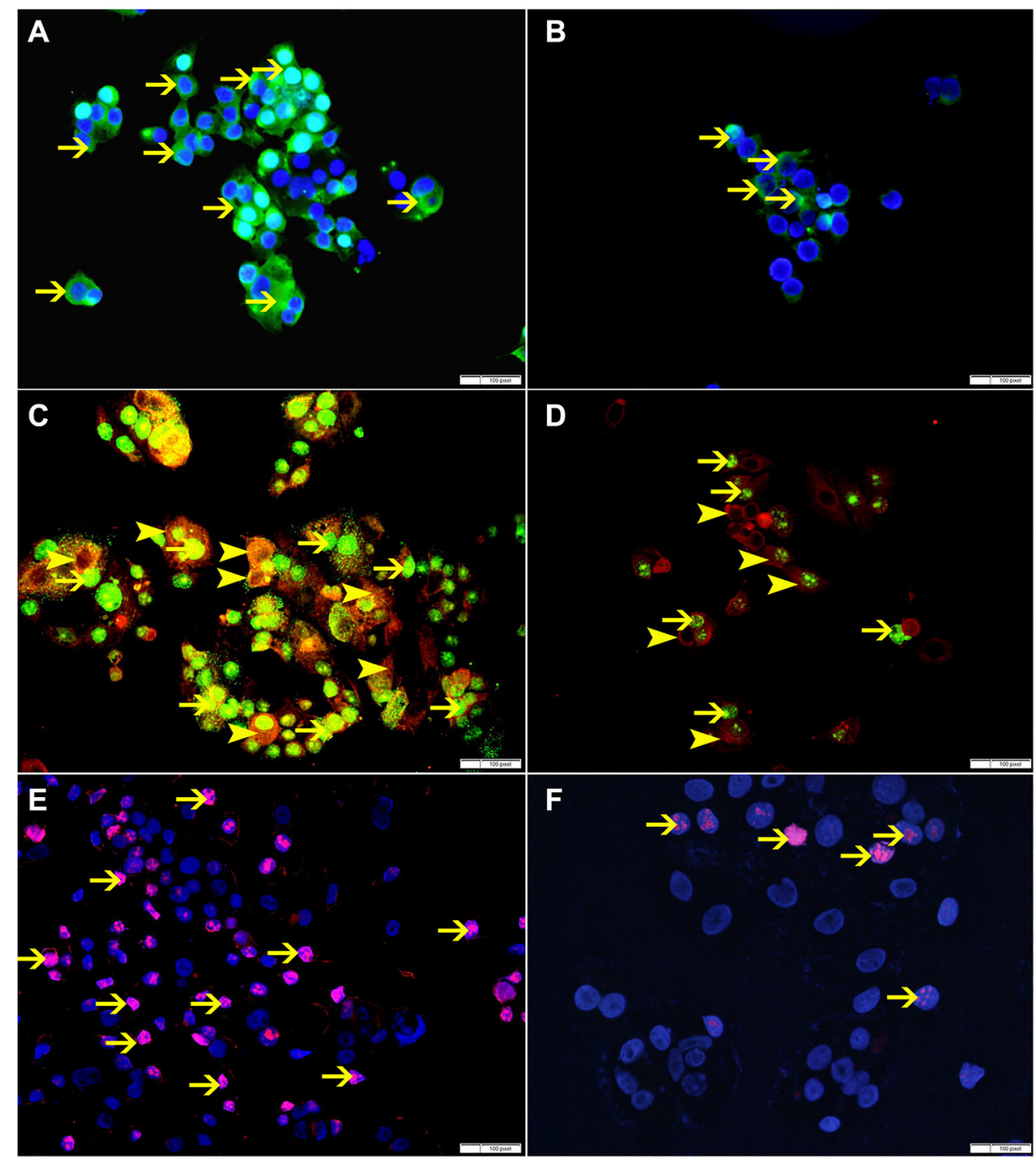

Figure 12: (A) Showing high cytoplasmic expression of p-NFKB by non-treated MCF-7 cells (arrow). (B) Showing lower cytoplasmic expression of p-NFKB by SO $60 \mathrm{mmol}$ treated MCF-7 cells (arrow). (C) Showing higher cytoplasmic expression of VEGF (arrowhead) and nuclear expression of BMI-1 (thin arrow) by non-treated MCF-7 cells. (D) Showing lower cytoplasmic expression of VEGF (arrowhead) and nuclear expression of BMI-1 (thin arrow) by SO $60 \mathrm{mmol}$ treated MCF-7 cells. (E) Showing higher number of cells expressing ki-67 in non-treated MCF-7 cells (arrow). (F) Showing lower number of cells expressing ki-67 in SO 60 mmol treated MCF-7 cells (arrow). 


\section{Biochemical estimations}

The cells were harvested by trypsinization. The obtained cell pellet was suspended in PBS and that suspension was used for biochemical estimations. Superoxide dismutase (SOD) was assayed by the method of Kakkar et al. [27]. Nicotinamide adenine dinucleotide (NADH), phenazine methosulphate, and nitroblue tetrazolium formazon formation are all inhibited in this assay. The reaction was initiated by the addition of NADH. For a set period of time, a known amount of enzyme preparation was permitted to react with $\mathrm{H}_{2} \mathrm{O}_{2}$ in the presence of glutathione (GSH). The GSH material that remained after the reaction was then calculated. The total GSH content was measured based on the development of a yellow color when 5,5'-dithiobis-2-nitrobenzoic acid was added to compound containing sulfhydryl groups [28].

\section{Lactate dehydrogenase A activity}

LDH-A Assay kit (Sigma, USA) was used to determine the intracellular LDHA activity. In this test, LDH-A reduces NAD to NADH, which interacts with a specific probe to produce a color $\left(\lambda_{\max }=450 \mathrm{~nm}\right)$, LDH-A level was measured using enzymatic colorimetric methods on Roche/Hitachi Cobas C systems (Integra 400 Plus, Germany). Results were expressed as percentage of LDH-A activity normalized to protein concentration.

\section{Western blotting}

After treatment, cells were lysed and extracted the protein with protease inhibitor added RIPA lysis buffer. The protein concentration was measured by using BCA reagent. Proteins $(50 \mu \mathrm{g})$ were resolved on polyacrylamide gels [29]. The gels were transferred into polyvinylidene difluoride (PVDF) membrane [30], and then blocked with $5 \%$ fat-free dry milk in PBS-T for $1 \mathrm{~h}$. Blots will be then incubated with primary antibodies (anti- LDHA antibodyRabbit monoclonal 1:1000, anti-pyruvate dehydrogenase - Rabbit monoclonal 1:1000, anti- VDAC antibody Rabbit monoclonal 1:100, anti- Bax antibody - Rabbit monoclonal 1:1000, anti- cleaved caspase-3 antibody - Rabbit polyclonal 1:1000, anti- cleaved caspase-8 antibody - Rabbit monoclonal 1:1000, anti- cleaved caspase-9 antibody - Rabbit monoclonal 1:1000, anticytochrome C antibody - Rabbit monoclonal, 1:1000, anti-beta actin antibody Rabbit monoclonal, 1:1000, (Cell signaling technology, Danvers, MA, USA), and anti- Bcl2 antibody - Rabbit Polyclonal 1:1000, (Abcam, Cambridge, MA, USA) overnight at $4{ }^{\circ} \mathrm{C}$. Next day, blots were washed and then incubated with HRP-conjugated secondary antibodies and protein bands developed using ECL plus substrate (Thermo Pierce). Protein bands were visualized by a laser scanner (Typhoon FLA 9500, GE Healthcare Bio-Sciences AB, Sweden). Quantitation of protein was performed using the software Image J. Protein of interest was normalized against $\beta$ actin to check equal loading.

\section{Immunofluorescent staining}

Both HeLa cells and MCF7 cells were grown on coverslips in 6-well flat-bottom plates as non-treated wells and SO $60 \mathrm{mmol}$ treated wells. Following the attachment of the cells to the coverslips and become confluent, treatment with SO $60 \mathrm{mmol}$ will be started for 24 hours followed by washing the coverslips with PBS for 3 times then appropriate primary antibodies (anti-Bax antibody (Rabbit monoclonal, 1:50, Cell signaling technology, Danvers, MA, USA), anti- VDAC antibody (Rabbit monoclonal, 1:50, Cell signaling technology, Danvers, MA, USA), anti- cleaved caspase- 3 antibody (Rabbit polyclonal, 1:50, Cell signaling technology, Danvers, MA, USA), anti- Bcl-xL antibody (Rabbit monoclonal, 1:50, Cell signaling technology, Danvers, MA, USA), antiphospho-NF kappa B antibody (Rabbit monoclonal, 1:50, Abcam, Cambridge, MA, USA), anti-BMI-1 antibody (Rabbit monoclonal, 1:50, Cell Marque, Rocklin, CA, USA), anti- VEGF antibody (mouse monoclonal, 1:50, DAKO, Agilent, Santa Clara, CA, USA), anti- Ki-67 antibody (mouse monoclonal, 1:50, DAKO, Agilent, Santa Clara, CA, USA), will be added to the treated and untreated wells and kept for 24 hours. For double labeling a second primary antibody will be added for another 24 hour followed by washing. Then coverslips will be washed with PBS for 3 times and then Alexa Fluor 488 labeled donkey anti-rabbit antibody will be added for one hour followed by washing with PBS for 3 times. For double labeling Alexa Fluor 488 labeled donkey anti-rabbit antibody will be added for one hour followed by washing with PBS for 3 times and then Rhodamine labeled donkey anti-mouse antibody will be added followed by washing with PBS for 3 times. Afterward, coverslips will be mounted on slides using DAPI IF mounting media.

\section{Statistical analysis}

The statistical analyses were performed using GraphPad Prism Software version 5. The comparisons between the various groups were achieved by one-way analysis of variance (ANOVA), followed by NewmanKeuls multiple range tests. Data were presented in mean \pm standard error (S.E). $P$ values $<0.05$ were considered significant.

\section{Author contributions}

All authors made a significant contribution in the scientific quality of the paper, fulfilling the ICMJE criteria. All authors approved the submitted version of the manuscript and agreed to be accountable for all aspects of 
the work. S.A introduced the concept, designed the study, analyzed and interpreted the data, designed the figures and wrote the paper. K.K performs all laboratory techniques, and participates in the analysis of data and writing the manuscript. M.S performed immunofluorescent staining and related cell culture technique.

\section{ACKNOWLEDGMENTS}

The authors would like to thank College of Medicine \& Health Sciences, UAE University for their support of our study.

\section{CONFLICTS OF INTEREST}

The authors declare no conflicts of interest.

\section{FUNDING}

The project is partially supported by Terry Fox grant, $21 \mathrm{MO} 79$.

\section{REFERENCES}

1. Warburg O. On respiratory impairment in cancer cells. Science. 1956; 124:269-70. [PubMed]

2. Kim JW, Dang CV. Cancer's molecular sweet tooth and the Warburg effect. Cancer Res. 2006; 66:8927-30. https://doi. org/10.1158/0008-5472.CAN-06-1501. [PubMed]

3. Goldman RD, Kaplan NO, Hall TC. Lactic dehydrogenase in human neoplastic tissues. Cancer Res. 1964; 24:389-99. [PubMed]

4. Fantin VR, St-Pierre J, Leder P. Attenuation of LDH-A expression uncovers a link between glycolysis, mitochondrial physiology, and tumor maintenance. Cancer Cell. 2006; 9:425-34. https://doi.org/10.1016/j. ccr.2006.04.023. [PubMed]

5. Le A, Cooper CR, Gouw AM, Dinavahi R, Maitra A, Deck LM, Royer RE, Vander Jagt DL, Semenza GL, Dang CV. Inhibition of lactate dehydrogenase A induces oxidative stress and inhibits tumor progression. Proc Natl Acad Sci U S A. 2010; 107:2037-42. https://doi.org/10.1073/ pnas.0914433107. [PubMed]

6. Wang ZY, Loo TY, Shen JG, Wang N, Wang DM, Yang DP, Mo SL, Guan XY, Chen JP. LDH-A silencing suppresses breast cancer tumorigenicity through induction of oxidative stress mediated mitochondrial pathway apoptosis. Breast Cancer Res Treat. 2012; 131:791-800. https://doi. org/10.1007/s10549-011-1466-6. [PubMed]

7. Valvona CJ, Fillmore HL, Nunn PB, Pilkington GJ. The Regulation and Function of Lactate Dehydrogenase A: Therapeutic Potential in Brain Tumor. Brain Pathol. 2016; 26:3-17. https://doi.org/10.1111/bpa.12299. [PubMed]

8. Fiume L, Manerba M, Vettraino M, Di Stefano G. Impairment of aerobic glycolysis by inhibitors of lactic dehydrogenase hinders the growth of human hepatocellular carcinoma cell lines. Pharmacology. 2010; 86:157-162. https://doi.org/10.1159/000317519. [PubMed]

9. Yao F, Zhao T, Zhong C, Zhu J, Zhao H. LDHA is necessary for the tumorigenicity of esophageal squamous cell carcinoma. Tumour Biol. 2013; 34:25-31. https://doi. org/10.1007/s13277-012-0506-0. [PubMed]

10. Rong Y, Wu W, Ni X, Kuang T, Jin D, Wang D, Lou W. Lactate dehydrogenase A is overexpressed in pancreatic cancer and promotes the growth of pancreatic cancer cells. Tumour Biol. 2013; 34:1523-30. https://doi.org/10.1007/ s13277-013-0679-1. [PubMed]

11. Wang X, Xu L, Wu Q, Liu M, Tang F, Cai Y, Fan W, Huang $\mathrm{H}, \mathrm{Gu} \mathrm{X}$. Inhibition of LDHA deliver potential anticancer performance in renal cell carcinoma. Urol Int. 2017; 99:237-44. https://doi.org/10.1159/000445125. [PubMed]

12. Zhao Z, Han F, Yang S, Wu J, Zhan W. Oxamate-mediated inhibition of lactate dehydrogenase induces protective autophagy in gastric cancer cells: involvement of the AktmTOR signaling pathway. Cancer Lett. 2015; 358:17-26. https://doi.org/10.1016/j.canlet.2014.11.046. [PubMed]

13. Redza-Dutordoir M, Averill-Bates DA. Activation of apoptosis signaling pathways by reactive oxygen species. Biochim Biophys Acta. 2016; 1863:2977-92. https://doi. org/10.1016/j.bbamcr.2016.09.012. [PubMed]

14. Franco R, Sánchez-Olea R, Reyes-Reyes EM, Panayiotidis MI. Environmental toxicity, oxidative stress and apoptosis: ménage à trois. Mutat Res. 2009; 674:3-22. https://doi. org/10.1016/j.mrgentox.2008.11.012. [PubMed]

15. Franco R, Panayiotidis MI, Cidlowski JA. Glutathione depletion is necessary for apoptosis in lymphoid cells independent of reactive oxygen species formation. J Biol Chem. 2007; 282:30452-65. https://doi.org/10.1074/jbc. M703091200. [PubMed]

16. Das CK, Parekh A, Parida PK, Bhutia SK, Mandal M. Lactate dehydrogenase A regulates autophagy and tamoxifen resistance in breast cancer. Biochim Biophys Acta Mol Cell Res. 2019; 1866:1004-18. https://doi. org/10.1016/j.bbamcr.2019.03.004. [PubMed]

17. Lemasters JJ, Holmuhamedov E. Voltage-dependent anion channel (VDAC) as mitochondrial governator--thinking outside the box. Biochim Biophys Acta. 2006; 1762:181-90. https://doi.org/10.1016/j.bbadis.2005.10.006. [PubMed]

18. Tsujimoto Y, Shimizu S. The voltage-dependent anion channel: an essential player in apoptosis. Biochimie. 2002; 84:187-93. https://doi.org/10.1016/s0300-9084(02)013706. [PubMed]

19. Zalk R, Israelson A, Garty ES, Azoulay-Zohar H, ShoshanBarmatz V. Oligomeric states of the voltage-dependent anion channel and cytochrome c release from mitochondria. Biochem J. 2005; 386:73-83. https://doi.org/10.1042/ BJ20041356. [ [PubMed]

20. Hata AN, Engelman JA, Faber AC. The BCL2 Family: Key Mediators of the Apoptotic Response to Targeted Anticancer 
Therapeutics. Cancer Discov. 2015; 5:475-87. https://doi. org/10.1158/2159-8290.CD-15-0011. [PubMed]

21. McCommis KS, Baines CP. The role of VDAC in cell death: friend or foe? Biochim Biophys Acta. 2012; 1818:1444-50. https://doi.org/10.1016/j.bbamem.2011.10.025. [PubMed]

22. Gonclaves RP, Buzhynskyy N, Prima V, Sturgis JN, Scheuring S. Supramolecular assembly of VDAC in native mitochondrial outer membranes. J Mol Biol. 2007; 369:413-18. https://doi.org/10.1016/j.jmb.2007.03.063. [PubMed]

23. Zheng Y, Shi Y, Tian C, Jiang C, Jin H, Chen J, Almasan A, Tang H, Chen Q. Essential role of the voltage-dependent anion channel (VDAC) in mitochondrial permeability transition pore opening and cytochrome $\mathrm{c}$ release induced by arsenic trioxide. Oncogene. 2004; 23:1239-47. https:// doi.org/10.1038/sj.onc.1207205. [PubMed]

24. Shimizu S, Narita M, Tsujimoto Y. Bcl-2 family proteins regulate the release of apoptogenic cytochrome c by the mitochondrial channel VDAC. Nature. 1999; 399:483-87. https://doi.org/10.1038/20959. [PubMed]

25. Baumgartner HK, Gerasimenko JV, Thorne C, Ashurst LH, Barrow SL, Chvanov MA, Gillies S, Criddle DN, Tepikin AV, Petersen OH, Sutton R, Watson AJ, Gerasimenko OV. Caspase-8-mediated apoptosis induced by oxidative stress is independent of the intrinsic pathway and dependent on cathepsins. Am J Physiol Gastrointest Liver Physiol. 2007; 293:G296-307. https://doi.org/10.1152/ajpgi.00103.2007. [PubMed]

26. Nishi K, Iwaihara Y, Tsunoda T, Doi K, Sakata T, Shirasawa $\mathrm{S}$, Ishikura S. ROS-induced cleavage of NHLRC2 by caspase- 8 leads to apoptotic cell death in the HCT116 human colon cancer cell line. Cell Death Dis. 2017; 8:3218. https://doi.org/10.1038/s41419-017-0006-7. [PubMed]

27. Kakkar P, Das B, Viswanathan PN. A modified spectrophotometric assay of superoxide dismutase. Indian J Biochem Biophys. 1984; 21:130-32. [PubMed]

28. Ellman GL. Tissue sulfhydryl groups. Arch Biochem Biophys. 1959; 82:70-77. https://doi.org/10.1016/00039861(59)90090-6. [PubMed]

29. Laemmli UK. Cleavage of structural proteins during the assembly of the head of bacteriophage T4. Nature. 1970; 227:680-85. https://doi.org/10.1038/227680a0. [PubMed]

30. Towbin H, Staehelin T, Gordon J. Electrophoretic transfer of proteins from polyacrylamide gels to nitrocellulose sheets: procedure and some applications. Proc Natl Acad Sci U S A. 1979; 76:4350-54. https://doi.org/10.1073/ pnas.76.9.4350. [PubMed] 